\title{
Molecular identification of differentially regulated genes in the hydrothermal-vent species Bathymodiolus thermophilus and Paralvinella pandorae in response to temperature Isabelle Boutet $^{1,2}$, Didier Jollivet ${ }^{1,2}$, Bruce Shillito ${ }^{3}$, Dario Moraga ${ }^{4}$ and Arnaud Tanguy*1,2
}

\author{
Address: ${ }^{1}$ CNRS, UMR 7144, Adaptation et Diversité en Milieu Marin, Station Biologique, de Roscoff, 29682 Roscoff, France, ${ }^{2}$ UPMC Univ Paris \\ 06, UMR 7144, Equipe Génétique et Adaptation en Milieu Extrême, Station Biologique de Roscoff, 29682 Roscoff, France, ${ }^{3}$ UPMC Université Paris \\ 6, UMR 7138, Systématique, Adaptation et Evolution, 75005 Paris, France and ${ }^{4}$ UMR CNRS 6539, Laboratoire des Sciences de l'Environnement \\ Marin, Institut Universitaire Européen de la Mer, Université de Bretagne Occidentale, Place Nicolas Copernic, 29280 Plouzané, France \\ Email: Isabelle Boutet - boutet@sb-roscoff.fr; Didier Jollivet - jollivet@sb-roscoff.fr; Bruce Shillito - Bruce.Shillito@snv-jussieu.fr; \\ Dario Moraga - dario.moraga@univ-brest.fr; Arnaud Tanguy* - atanguy@sb-roscoff.fr \\ * Corresponding author
}

Published: 13 May 2009

BMC Genomics 2009, 10:222 doi:10.1186/|47|-2164-10-222
Received: 24 July 2008

Accepted: 13 May 2009

This article is available from: http://www.biomedcentral.com/I47I-2/64/I0/222

(C) 2009 Boutet et al; licensee BioMed Central Ltd.

This is an Open Access article distributed under the terms of the Creative Commons Attribution License (http://creativecommons.org/licenses/by/2.0), which permits unrestricted use, distribution, and reproduction in any medium, provided the original work is properly cited.

\begin{abstract}
Background: Hydrothermal vents and cold seeps represent oases of life in the deep-sea environment, but are also characterized by challenging physical and chemical conditions. The effect of temperature fluctuations on vent organisms in their habitat has not been well explored, in particular at a molecular level, most gene expression studies being conducted on coastal marine species. In order to better understand the response of hydrothermal organisms to different temperature regimes, differentially expressed genes (obtained by a subtractive suppression hybridization approach) were identified in the mussel Bathymodiolus thermophilus and the annelid Paralvinella pandorae irlandei to characterize the physiological processes involved when animals are subjected to long term exposure ( 2 days) at two contrasting temperatures $\left(10^{\circ}\right.$ versus $\left.20^{\circ} \mathrm{C}\right)$, while maintained at in situ pressures. To avoid a potential effect of pressure, the experimental animals were initially thermally acclimated for 24 hours in a pressurized vessel.

Results: For each species, we produced two subtractive cDNA libraries (forward and reverse) from sets of deep-sea mussels and annelids exposed together to a thermal challenge under pressure. RNA extracted from the gills, adductor muscle, mantle and foot tissue were used for $B$. thermophilus. For the annelid model, whole animals (small individuals) were used. For each of the four libraries, we sequenced 200 clones, resulting in 78 and 83 unique sequences in mussels and annelids (about $20 \%$ of the sequencing effort), respectively, with only half of them corresponding to known genes. Real-time PCR was used to validate differentially expressed genes identified in the corresponding libraries. Strong expression variations have been observed for some specific genes such as the intracellular hemoglobin, the nidogen protein, and Rab7 in P. pandorae, and the SPARC protein, cyclophilin, foot protein and adhesive plaque protein in B. thermophilus.
\end{abstract}

Conclusion: Our results indicate that mussels and worms are not responding in the same way to temperature variations. While the results obtained for the mussel $B$. thermophilus seem to indicate a metabolic depression (strong decrease in the level of mRNA expression of numerous genes) 
when temperature increased, the annelid $P$. pandorae mainly displayed a strong regulation of the mRNA encoding subunits and linkers of respiratory pigments and some proteins involved in membrane structure. In both cases, these regulations seem to be partly due to a possible cellular oxidative stress induced by the simulated thermal environment $\left(10^{\circ} \mathrm{C}\right.$ to $\left.20^{\circ} \mathrm{C}\right)$. This work will serve as a starting point for studying the transcriptomic response of hydrothermal mussels and annelids in future experiments in response to thermal stress at various conditions of duration and temperature challenge.

\section{Background}

The distribution of terrestrial, as well as marine, organisms is strongly influenced by environmental factors (variation, gradient, intensity), and temperature was identified as one of the most important. Temperature is known to affect the spatial distribution of species according to their thermal tolerance [1]. Environmental temperature challenge has a direct impact on ectothermic marine animals, and influences biological functions at all levels, from molecules to whole organisms [2,3]. Variation and/ or gradients of temperature are considered as strong selective factors $[4,5]$. Numerous studies dealing with the effect of temperature have been conducted on coastal marine species at the molecular, physiological and protein levels $[6,7]$. An elevation of temperature can increase reaction rates and affect reaction equilibrium through higher kinetic energy. In addition, high temperatures induce protein denaturation, resulting in complete and often irreversible loss of function [2].

Hydrothermal vents and cold seeps represent oases of life in the deep-sea environment but are also characterized by challenging environmental conditions, when compared to the surrounding deep-sea. The hydrothermal fluid is the result of chemical modifications of the deep-sea water by interaction with the hot rocks (near the magma chamber) during a long percolating period through the oceanic crust. The resulting fluid is a hot water (up to $400^{\circ} \mathrm{C}$ ), often anoxic, acidic ( $\mathrm{pH} 2$ ), and containing high concentrations of methane, carbon dioxide, sulfide, heavy metals, and arsenic-containing compounds [8-10]. As it comes out of the sea-floor, the hydrothermal fluid is chaotically mixed with the cold, more oxygenated deep-sea water. Abiotic factors such as changes in fluid flow, temperature and chemical composition affect species distributions at vents [11-13]. The endemic hydrothermal vent organisms live in the mixing zone according to their tolerance to - and requirements for- various factors (temperature, $\mathrm{pH}, \mathrm{O}_{2}$ concentration...). However, the effect of temperature variations on hydrothermal vent organisms has not been well studied, particularly at the molecular level. Available data on the vent mussel of genus Bathymodiolus are mainly focused on the effect of heavy metals and oxidative stress on enzymatic activities [14] and specific gene expression (e.g. metallothioneins) [15]. A few immune system-relevant genes have also been described [16], and a cDNA library from Bathymodiolus azoricus has been partially sequenced [17]. Numerous studies also described these mussels' symbiosis with chemoautotrophic bacteria, often at both the phylogenetic and the biochemical levels [18-20]. HSP70, a typical thermal stress marker, has also been studied in hydrothermal vent species in response to temperature and other parameters. The HSP70 gene has been characterized in the vent shrimps Mirocaris fortunata and Rimicaris exoculata [21], in the vent annelid Paralvinella grasslei [22], and variations in HSP70 protein content were correlated to variations of environmental parameters for the vent mussel $B$. azoricus [23]. In Alvinellidae, a polychaete family endemic of hydrothermal vents that includes the genera Alvinella and Paralvinella, hemoglobins were largely studied at both the molecular and the functional levels [24]. Recent studies demonstrated the temperature preference of vent worm species by incubating them along a thermal gradient ranging from 15 to $60^{\circ} \mathrm{C}[25,26]$. The existence of thermally sensitive alleles was shown for some proteins in P. pandorae compared to other species living at higher temperatures, such as A. pompejana, P. sulfincola or P. hessleri [27]. These data could be partly related to the species distribution in their respective habitats that mostly differ by their temperature range.

The vent mussel $B$. thermophilus is found under a wide range of environmental conditions on the East Pacific Rise. It may occur with tubeworms in areas of active hydrothermal flow where temperature and hydrogen sulfide concentrations are high, as well as in areas of diffuse flow, where the temperature and the concentration of hydrogen sulfide are much lower [28]. Studies have shown that $B$. thermophilus can quickly adapt to a wide range of environmental conditions (especially chemical changes) but usually lives between 4 and $14^{\circ} \mathrm{C}$ [29]. No studies report a thorough characterization of $P$. pandorae irlandei's habitat but this species is mainly found in the cracks at the base of the tubes of the vestimentiferan tubeworm Tevnia jerichonana [30] where it encounters temperatures ranging from 5 to $22^{\circ} \mathrm{C}$ [31]. Because temperature highly fluctuates in time, a thermal regime of $20^{\circ} \mathrm{C}$ therefore represents an upper thermal condition for both species whereas an average temperature of $10^{\circ} \mathrm{C}$ could be 
more related to their thermal preference. In this work, we used a suppression subtractive hybridization (SSH) approach to (1) verify if such a temperature challenge induces a transcriptomic response, (2) characterize genes and the physiological processes involved in response to temperature variations, and (3) compare common and specific responses attributable to these two highly-divergent species.

\section{Results}

\section{Mussel SSH libraries sequencing results}

The sequencing of 200 clones from the forward (individuals incubated at $10^{\circ} \mathrm{C}$ versus individuals exposed at $\left.20^{\circ} \mathrm{C}\right) \mathrm{SSH}$ library, as well as from the reverse library (individuals incubated at $20^{\circ} \mathrm{C}$ versus individuals exposed at $10^{\circ} \mathrm{C}$ ), allowed the identification of 78 unique sequences for $B$. thermophilus (19\% of the whole sequencing effort: other sequences are redundant). Table 1 shows the unique sequences obtained in both SSH libraries with the best E-values for the sequences when identified after Blast analysis. The identified sequences indicate that temperature regulates genes involved in various cell functions: (1) cell cycle regulation, DNA repair, protein regulation and transcription $(8.5 \%),(2)$ mitochondrial respiratory chain (4\%), (3) metabolism (6.4\%), (4) stress response and detoxification $(0.5 \%)$, (5) cell communication, membrane receptors and immune system $(10.2 \%)$, (6) cytoskeleton production and maintenance $(7.5 \%)$, (7) ribosomal proteins $(10 \%),(8)$ proteins of unknown function $(0.5 \%)$ and $(9)$ unknown sequences $(52 \%)$. A higher proportion $(60 \%)$ of the genes identified in our libraries were expressed in mussel exposed to $10^{\circ} \mathrm{C}$ and were mainly involved in metabolism, stress response, transcription and cytoskeleton.

\section{Annelid SSH libraries sequencing results}

The sequencing of 200 clones from the forward (individuals incubated at $10^{\circ} \mathrm{C}$ versus individuals exposed at $\left.20^{\circ} \mathrm{C}\right) \mathrm{SSH}$ library, as well as from the reverse library (individuals incubated at $20^{\circ} \mathrm{C}$ versus individuals exposed at $10^{\circ} \mathrm{C}$ ) allowed the identification of 83 different gene sequences for $P$. pandorae (20\% of the whole sequencing effort: the other sequences are redundant). Table 2 shows the unique sequences obtained in both SSH libraries with the best E-values for the sequences when identified after Blast analysis. The identified sequences indicate that temperature regulates the expression of genes involved in various cell functions: (1) respiratory chain $(9.6 \%),(2)$ sulfur and oxygen transport $(8.4 \%),(3)$ metabolism $(2.4 \%)$, (4) cell communication, membrane receptors and immune system $(4.8 \%),(5)$ cytoskeleton production and maintenance $(3.6 \%)$, (6) ribosomal proteins $(8.4 \%),(7)$ proteins of unknown function $(2.4 \%)$ and (8) unknown sequences (60.4\%). Interestingly, most transcripts identified in the reverse subtractive library cor- respond to genes involved in the respiratory chain and in oxygen transport. A high proportion of unknown sequences were also obtained limiting the identification of new temperature-regulated putative candidate gene.

\section{Relative expression level of some target genes}

Levels of expression of 20 transcripts obtained in the $B$. thermophilus library and 14 transcripts identified in the $P$. pandorae library were quantified from pools of individuals of each thermal condition by using real-time PCR. For all the genes, we showed that the differential expression observed for the genes corresponds to the library they came from. In addition, stronger differential expressions were observed in B. thermophilus for metabolic genes such as S-adenosylhomocysteinase-hydrolase, arginine kinase or $\Delta 5$-desaturase, and some genes such as secreted protein acidic rich in cystein (SPARC, a basal membrane component), elongation factor beta, actin and proteins related to mussel mobility (foot protein and adhesive plaque matrix protein) (Table 3). While it was identified in the reverse library, the gene encoding the kalicludine did not display a clear differential expression between the two experimental conditions. In $P$. pandorae, differences between levels of expression of the two sets of experimented individuals were higher than those observed in mussels. Some genes also showed a very high level of expression in samples exposed to $10^{\circ} \mathrm{C}$ as compared to those exposed at $20^{\circ} \mathrm{C}$, especially for the secreted nidogen domain protein, Rab7, the intracellular hemoglobin and the ribosomal protein S16 that were strongly inhibited in annelids exposed to $20^{\circ} \mathrm{C}$. Almost all genes encoding subunits of hemoglobins (except linker L2) displayed a coherent expression pattern of up-regulation in annelids exposed to $20^{\circ} \mathrm{C}$ (Table 4).

\section{Discussion}

In the present paper, we described and analyzed gene expression in two hydrothermal species in response to two temperatures, one included in the range of temperature encountered by both species $\left(10^{\circ} \mathrm{C}\right)$, and the other near (for worms) or above (for mussels) their thermal limit range $\left(20^{\circ} \mathrm{C}\right)$. The following parts of the discussion deal with the respective responses of these two species in terms of differences and common features typifying their ability to adapt different thermal regimes.

\section{Unidentified sequences}

Over $50 \%$ of the sequences for each species could not be identified based on homologies. This may be due to the limited amount of data available for invertebrates, or to the SSH protocol itself that requires the use of a restriction enzyme, possibly leaving only the UTRs for cloning. This may explain that we did not obtain typical heat stress proteins such as the inducible heat shock protein 70 (HSP70). This could also be due to the long term acclima- 
Table I: Regulated genes identified in the SSH libraries of thermally challenged Bathymodiolus thermophilus with significant database matches (only sequences with E-value above 0.005 are shown).

\begin{tabular}{|c|c|c|c|c|}
\hline Homolog (protein); Blastx value & Homolog species & $\begin{array}{l}\text { Insert size } \\
\quad \text { (bp) }\end{array}$ & $\begin{array}{l}\text { Accession } \\
\text { number }\end{array}$ & $\begin{array}{c}\text { SSH } \\
\text { library }\end{array}$ \\
\hline \multicolumn{5}{|c|}{ Cell cycle, DNA repair, protein regulation and transcription } \\
\hline Elongation factor I alpha; le-I4 & Mytilus galloprovincialis & 428 & GHI96568 & forward \\
\hline Elongation factor beta; $2 \mathrm{e}-05$ & Strongylocentrotus purpuratus & 153 & GHI96577 & forward \\
\hline Elongation factor-2; 9e-89 & Hutchinsoniella macracantha & 577 & GHI96570 & forward \\
\hline S-cyclophilin; 2e-I4 & Gallus gallus & 384 & GHI96575 & forward \\
\hline $\mathrm{H} 3$ histone; $4 \mathrm{e}-43$ & Mus musculus & 538 & GHI96576 & reverse \\
\hline Myc homolog; 7e-10 & Crassostrea virginica & 704 & GHI96563 & reverse \\
\hline \multicolumn{5}{|l|}{ Respiratory chain } \\
\hline Cytochrome c oxidase subunit II; 5 e- 32 & Lampsilis ornata & 424 & GHI96573 & reverse \\
\hline Cytochrome c oxidase subunit III; I e-20 & Arbacia lixula & 260 & GHI96584 & reverse \\
\hline ATP synthase; 3e-2I & Bos taurus & 415 & GHI96588 & reverse \\
\hline \multicolumn{5}{|l|}{ Metabolism } \\
\hline S-adenosylhomocysteine hydrolase $2 \mathrm{e}-60$ & $\begin{array}{c}\text { Branchiostoma belcheri } \\
\text { tsingtaunese }\end{array}$ & 505 & GHI 96574 & forward \\
\hline Cytosolic Lactate/malate dehydrogenase; 2e-14 & Caenorhabditis elegans & 421 & GHI96590 & forward \\
\hline Arginine kinase; & Octopus vulgaris & 135 & GHI96579 & forward \\
\hline Anhydrase carbonic $2 ; 2 \mathrm{e}-02$ & Oncorhynchus mykiss & 114 & GHI96567 & forward \\
\hline Delta-5-desaturase; $4 \mathrm{e}-25$ & Strongylocentrotus purpuratus & 195 & GHI96582 & forward \\
\hline \multicolumn{5}{|l|}{ Stress response and detoxication } \\
\hline Glutathione peroxidase; 0.001 & Bombyx mori & 101 & GHI96562 & forward \\
\hline Heat Shock Protein 90; 4e-2I & Tetraodon nigroviridis & 156 & GHI9656I & forward \\
\hline \multicolumn{5}{|c|}{ Cell communication, membrane receptors, immune system } \\
\hline Kalicludine I; 3e-16 & Anemonia sulcata & 406 & GHI96560 & reverse \\
\hline Techylectin-5A; 8e-29 & Tachypleus tridentatus & 337 & GHI96558 & reverse \\
\hline Electron-transfer-flavoprotein; $4 \mathrm{e}-57$ & Strongylocentrotus purpuratus & 535 & GHI96557 & reverse \\
\hline $\mathrm{Itm} \mid$ protein, $4 \mathrm{e}-27$ & Xenopus laevis & 179 & GHI96556 & reverse \\
\hline $\mathrm{Clq}$-like adipose specific protein; $2 \mathrm{e}-07$ & Salvelinus fontinalis & 570 & GHI96594 & reverse \\
\hline
\end{tabular}


Table I: Regulated genes identified in the SSH libraries of thermally challenged Bathymodiolus thermophilus with significant database matches (only sequences with E-value above 0.005 are shown). (Continued)

\begin{tabular}{|c|c|c|c|c|}
\hline$\beta$-I,3-N-acetylglucosaminyltransferase 6; 5e-48 & Homo sapiens & 586 & GHI9657I & reverse \\
\hline Secreted protein, acidic, rich in cysteine SPARC; $2 \mathrm{e}-20$ & Artemia franciscana & 523 & GHI 96580 & forward \\
\hline Defensin; le-04 & Haliotis discus hannai & 105 & GHI 96559 & forward \\
\hline \multicolumn{5}{|l|}{ Cytoskeleton production and maintenance } \\
\hline$\alpha$-2-tubulin; 4e-27 & Gecarcinus lateralis & 348 & GHI 96585 & forward \\
\hline Actin; Ie-35 & Mytilus galloprovincialis & 541 & GHI 96578 & forward \\
\hline Adhesive plaque matrix protein; $6 \mathrm{e}-06$ & Mytilus galloprovincialis & 291 & GHI96589 & forward \\
\hline Foot protein 2; le-6 & Mytilus edulis & 108 & GHI9658I & forward \\
\hline Pedal retractor muscle myosin; $6 \mathrm{e}-50$ & Mytilus galloprovincialis & 426 & GHI96564 & forward \\
\hline Hemicentin; fibulin 6; 2e-14 & Rattus norvegicus & 304 & GHI96587 & reverse \\
\hline \multicolumn{5}{|l|}{ Ribosomal proteins } \\
\hline Ribosomal protein L3; 2e-55 & Argopecten irradians & 495 & GHI9659I & forward \\
\hline Ribosomal protein L4; 4e-80 & Latimeria chalumnae & 926 & GHI96586 & forward \\
\hline Ribosomal protein SI4; 3e-04 & Rattus norvegicus & 256 & GHI 96555 & forward \\
\hline Ribosomal protein SI5; Ie-64 & Argopecten irradians & 465 & GHI96566 & forward \\
\hline Ribosomal protein SI9; 2e-09 & Chlamys farreri & 362 & GHI96569 & forward \\
\hline Ribosomal protein S25; Ie-28 & Crassostrea gigas & 379 & GHI 96583 & forward \\
\hline Ribosomal protein LI5; 7e-16 & Siniperca kneri & 214 & GHI96565 & reverse \\
\hline QM protein; 7e-II & Apis mellifera & 622 & GHI96572 & reverse \\
\hline \multicolumn{5}{|l|}{ Unknown function } \\
\hline CG33I7I-PC, isoform C; 4e-07 & Drosophila melanogaster & 615 & GHI96592 & reverse \\
\hline Repeat organellar protein-related; le-05 & Plasmodium yoelii yoelii & 765 & GHI96595 & reverse \\
\hline
\end{tabular}

\section{Unidentified sequences}

39 sequences

GHI 96596 to $\mathrm{GH} 196632$

Forward: genes over-expressed at $10^{\circ} \mathrm{C}$ versus $20^{\circ} \mathrm{C}$;

Reverse: genes over-expressed at $20^{\circ} \mathrm{C}$ versus $10^{\circ} \mathrm{C}$.

tion (about 2 days) offered to the animals leading to an attenuation of the stress machinery with time. None of the SSH libraries (mussel and annelid) indeed contained mRNA coding for any HSP70s, that are involved in the protection of other proteins from denaturation caused by a variety of stressors [32,33]. Available data dealing with
HSP70 in hydrothermal species were only obtained from polychaetes, mussels and shrimps exposed to brief heat shocks $[21,22,34]$. In previous studies, a positive correlation between the levels of DNA strand breakage and HSP70 expression in response to decompression stress were also found by Pruski and Dixon [35]. In the shrimp 
Table 2: Regulated genes identified in the SSH libraries of thermal exposed Paralvinella pandorae irlandei with significant database matches (E-value above 0.005).

\begin{tabular}{|c|c|c|c|c|}
\hline Homolog (protein); Blastx value & Homolog Species & Insert size (bp) & Accession number & SSH library \\
\hline \multicolumn{5}{|l|}{ Respiratory chain } \\
\hline Cytochrome c oxidase subunit I; le-73 & Littorina saxatilis & 772 & GHI96478 & reverse \\
\hline Cytochrome oxidase subunit II; le-46 & Lumbricus terrestris & 715 & GHI96499 & reverse \\
\hline Cytochrome c oxidase subunit III; $2 \mathrm{e}-34$ & Albula glossodonta & 457 & GHI96480 & reverse \\
\hline Cytochrome c oxidase polypeptide Va; le-20 & Strongylocentrotus purpuratus & 149 & GHI96490 & reverse \\
\hline Ubiquinol-cytochrome c reductase complex; 4e-23 & Mus musculus & 537 & GHI96502 & reverse \\
\hline Cytochrome b; le-23 & Urechis caupo & 258 & GHI96495 & reverse \\
\hline NADH dehydrogenase subunit I; $4 \mathrm{e}-48$ & Urechis caupo & 571 & GHI96493 & reverse \\
\hline NADH dehydrogenase subunit $6 ; 7 \mathrm{e}-05$ & Clymenella torquata & 190 & GHI9650I & reverse \\
\hline
\end{tabular}

\section{Sulfur and oxygen transport}

\begin{tabular}{|c|c|c|c|c|}
\hline Hemoglobin A2c chain; 3e-3I & Arenicola marina & 569 & GHI96487 & reverse \\
\hline Hemoglobin $\mathrm{BI}$ chain precursor; $4 \mathrm{e}-2 \mathrm{I}$ & Arenicola marina & 326 & GHI96479 & reverse \\
\hline Hemoglobin B2 chain; Ie-12 & Arenicola marina & 516 & GHI9649I & reverse \\
\hline Hemoglobin linker LY precursor; 5e-86 & Riftia pachyptila & 529 & GHI96505 & reverse \\
\hline Extracellular globin linker LI precursor; 0.002 & Alvinella pompejana & 335 & GHI96504 & reverse \\
\hline Hemoglobin linker L2 precursor; 0.005 & Alvinella pompejana & 727 & GHI96483 & forward \\
\hline Intracellular hemoglobin; 5e-4I & Alvinella pompejana & 547 & GHI96492 & forward \\
\hline \multicolumn{5}{|l|}{ Metabolism } \\
\hline Trypsin; 6e-60 & Litopenaeus vannamei & 661 & GHI96494 & reverse \\
\hline S-adenosylhomocysteine hydrolase; $2 \mathrm{e}-66$ & Branchiostoma $v$ & 529 & GHI96476 & forward \\
\hline \multicolumn{5}{|c|}{ Cell communication, membrane receptors, immune system } \\
\hline Lipid binding protein 9; 5e-05 & Caenorhabditis elegans & 463 & GHI9648I & forward \\
\hline GTP-binding protein (rab7); 7e-89 & Canis familiaris & 641 & GHI96489 & forward \\
\hline Xylan endohydrolase isoenzyme, $6 \mathrm{e}-22$ & Arabidopsis thaliana & 455 & GHI96472 & reverse \\
\hline Cyclophilin B; 4e-14 & Gallus gallus & 384 & GHI96477 & reverse \\
\hline \multicolumn{5}{|l|}{ Cytoskeleton production and maintenance } \\
\hline Chymotrysin; 4e-II & Lumbricus rubellus & 230 & GHI96484 & forward \\
\hline
\end{tabular}


Table 2: Regulated genes identified in the SSH libraries of thermal exposed Paralvinella pandorae irlandei with significant database matches (E-value above 0.005). (Continued)

\begin{tabular}{|c|c|c|c|c|}
\hline Secreted nidogen domain protein; $4 \mathrm{e}-08$ & Strongylocentrotus purpuratus & 325 & GHI96473 & forward \\
\hline Actin Al; $2 \mathrm{e}-35$ & Haliotis iris & 541 & GHI96475 & forward \\
\hline \multicolumn{5}{|l|}{ Ribosomal proteins } \\
\hline Ribosomal protein L5; 3e-58 & Rattus norvegicus & 423 & GHI96497 & reverse \\
\hline Ribosomal protein L28; 6e-07 & Haliotis asinina & 262 & GHI96486 & reverse \\
\hline Ribosomal protein L24; Ie-38 & Danio rerio & 439 & GHI96482 & forward \\
\hline Ribosomal protein S3; 3e-30 & Crassostrea gigas & 205 & GHI96474 & forward \\
\hline Ribosomal protein SI6; 2e-4I & Gallus gallus & 337 & GHI96500 & forward \\
\hline Ribosomal protein SA; 8e-43 & Xenopus tropicalis & 514 & GHI96496 & forward \\
\hline Ribosomal protein $\mathrm{PI}$; 2e-II & Drosophila yakuba & 444 & GHI96498 & forward \\
\hline \multicolumn{5}{|l|}{ Unknown function } \\
\hline CGI4235-PA, isoform A; le-27 & Tribolium castaneum & 483 & GHI96488 & forward \\
\hline CBG I9860; 2e-08 & Caenorhabditis briggsae & 266 & GHI 96485 & reverse \\
\hline
\end{tabular}

Forward: genes over-expressed at $10^{\circ} \mathrm{C}$ versus $20^{\circ} \mathrm{C}$; Reverse: genes over- expressed at $20^{\circ} \mathrm{C}$ versus $10^{\circ} \mathrm{C}$.

Rimicaris exoculata, regulation of HSP70 in response to temperature was detected at the protein level [21], but no data related to HSP70 gene regulation is available so far.

\section{Is P. pandorae better adapted to higher temperature than B. thermophilus?}

Metabolic adjustments in response to thermal challenges are essential for aquatic ectotherms, whose body temperature fluctuates over the full range of temperature in their habitat [36]. Temperature can also influence metabolic regulation, eliciting transition to anaerobiosis even in oxygenated waters [37]. A high thermal sensitivity of metabolism over the environmental range is associated to increased long-term metabolic costs and with a lower tolerance to extreme temperatures. Classically, lowering metabolic rate and, thus energy saving is also considered as one of the most important adaptations for hypoxia endurance $[38,39]$. Adaptation to these conditions has resulted in reduced growth rates, as well as reduced development and metabolism [40]. Previous studies conducted on the marine gastropod Littorina saxatilis showed that an acute long-term temperature increase could disturb metabolism, leading to progressive metabolic depression and adverse changes in the cellular energy status due to its transition to partial anaerobiosis [41]. Antarctic marine species are also much less capable to survive elevated temperatures [42] and calculated temperature envelopes for these organisms were 2-4 times smaller than those for temperate species [43]. Studies on the Mediterranean mussel Mytilus galloprovincialis showed that a long acclimation of up to 30 days at high temperatures (18 to $30^{\circ} \mathrm{C}$ ) leads to behavioral (increase of duration of valve closure), metabolic (metabolic depression with a shift from aerobic to anaerobic metabolism) and molecular (increase in HSPs protein levels) responses [44]. Interestingly, the deep-sea mussel $B$. thermophilus seems to share some general features with organisms living in polar oceans that are characterized by very stable low temperatures, below $5^{\circ} \mathrm{C}$. We first hypothesized that annelids were able to cope with a larger range of temperature compared to the mussels, because they were described as early colonizers of new chimneys at hydrothermal vents [45], and thus able to sustain highest temperatures, at least over short periods of time. While few genes seem to be regulated similarly between the two species (actin, mitochondrial cytochrome oxydase, S-adenosylhomocysteine hydrolase), most cell functions are very dissimilar, suggesting a different response of these organisms to temper- 
Table 3: mRNA expression of genes in B. thermophilus presented as a fold-change value with animals exposed at $10^{\circ} \mathrm{C}$ as a calibrator.

\begin{tabular}{|c|c|}
\hline Genes & Fold-change (calibration to $10^{\circ} \mathrm{C}$ ) \\
\hline \multicolumn{2}{|l|}{ Down-regulated at $20^{\circ} \mathrm{C}$} \\
\hline Defensin & 1192.69 \\
\hline Elongation Factor beta & 4.59 \\
\hline Ribosomal protein L3 & 6.23 \\
\hline Foot protein & 3.36 \\
\hline Pedal retractor muscle myosin & 5.17 \\
\hline Adhesive plaque matrix protein & 2.83 \\
\hline Actin & 4.03 \\
\hline Secreted Protein, Acidic, Rich in Cystein (SPARC) & 7.21 \\
\hline S-adenosylhomocysteine hydrolase & 5.24 \\
\hline Cyclofilin S & 4.35 \\
\hline$\Delta 5$-desaturase & 8.28 \\
\hline Carbonic anhydrase 2 & 11.39 \\
\hline Adenylate kinase & 6.59 \\
\hline Gluthatione peroxidase & 6.28 \\
\hline Cytosolic malate dehydrogenase & 8.75 \\
\hline HSP9O & 6.23 \\
\hline BthermESTI & 2.57 \\
\hline \multicolumn{2}{|l|}{ Up-regulated at $20^{\circ} \mathrm{C}$} \\
\hline Kalicludine & 1.06 \\
\hline Myc homolog & 12.30 \\
\hline Techylectin 5A & 6.63 \\
\hline
\end{tabular}

ature. The genes that were identified in the mussel libraries could indicate that this species tends to react as a stenoecious species rather than an euryecious species (as could be expected for organisms living in a highly fluctuating environment). A general depression is indeed observed in expression of Bathymodiolus genes involved in transcription/translation, mobility, energetic metabolism, and oxidative stress in response to temperature increase. Conversely, genes involved in cell disorder and immune system (ie myc-homolog, kalicludin...) are up-regulated at the highest temperature. No similar pattern is observed in $P$. pandorae, leading to the hypothesis that this species could better adapt to high temperatures.

A long exposure at a temperature of $20^{\circ} \mathrm{C}$ ( 43 hours) clearly appears to be a thermal physiological limit for $B$. thermophilus that lives in colder habitats. As mussels encounter short pulses of hot water under in situ conditions, it seems that the duration of the heat exposure is critical and probably more important than the tempera-

Table 4: mRNA expression of genes in P. pandorae presented as a fold-change value with animals exposed at $10^{\circ} \mathrm{C}$ as a calibrator.

\begin{tabular}{lc}
\hline Genes & Fold-change (calibration to $10^{\circ} \mathrm{C}$ ) \\
\hline Up-regulated at $20^{\circ} \mathrm{C}$ & 250 \\
Hemoglobin A2c & 31.25 \\
Hemoglobin B2 & 142.86 \\
Linker LI & 13.33 \\
PpandEST2 & 5.13 \\
Xylan endohydrolase & \\
\hline Down-regulated at $20^{\circ} \mathrm{C}$ & 1226.22 \\
Intracellular Hemoglobin & 4.03 \\
Linker L2 & 1278.29 \\
Secreted Nidogen domain protein & 35.51 \\
S-adenosylhomocysteine hydrolase & 20.46 \\
Chymotrypsinogen & 1.53 \\
PpandESTI & 1640.59 \\
Ribosomal protein SI6 & 1.80 \\
Lipid binding protein & 2469.49 \\
Rab 7 &
\end{tabular}


ture value itself. According to the experimental conditions used for this study, it remains difficult to evaluate how long $B$. thermophilus is really able to withstand a temperature of $20^{\circ} \mathrm{C}$ without severe physiological damage. Complementary experiments such as the determination of differential mortality kinetic in longer-term exposures and at different ranges of temperatures have to be performed in further studies to better understand the thermal resistance/response/adaptation of this species. As all individuals survived for about 2 days (43-hour experiment), $B$. thermophilus can deal with thermal stress for at least few days but it is not clear whether they can then recover from such stress.

The hypothesized limited adaptation of $B$. thermophilus to high temperature is also supported by a decrease of expression of nearly all genes identified in the mussels exposed to $20^{\circ} \mathrm{C}$, a pattern indicative of global metabolic depression. Among these genes, there were many ribosomal proteins and some elongation factors, indicating that the protein synthesis pathway was clearly involved in response to temperature. However, different ribosomal proteins are identified in both reverse and forward libraries showing a complex regulatory process (or the absence of regulation) in intra-molecular interactions in ribosomes. This result is commonly observed in transcriptomic studies in mollusks in response to various environmental parameters [46-49]. A higher number of ribosomal proteins were however identified in the mussel forward libraries suggesting a possible metabolic depression in samples exposed to $20^{\circ} \mathrm{C}$ when compared to those exposed at $10^{\circ} \mathrm{C}$. In $P$. pandorae libraries, similar pattern of down regulation at $20^{\circ} \mathrm{C}$ of 5 ribosomal proteins among the 7 identified is observed.

More specifically, it is noteworthy that several genes of the mussel energetic pathways were down-regulated. Among them, arginine kinase (ArgK) and cytosolic malate dehydrogenase $(\mathrm{cMDH})$ are found to be down regulated in mussels exposed to $20^{\circ} \mathrm{C}$. ArgK catalyzes the transfer of phosphate between ATP and arginine (arginine phosphate $+\mathrm{MgADP}^{-}+\mathrm{H}^{+} \leftrightarrow$ arginine $+\mathrm{MgATP}^{2-}$ ), and plays a critical role in cellular energy metabolism in invertebrates [50]. It also serves as an energy reserve because it can readily transfer phosphor-arginine to ATP when energy is needed $[51,52]$. However, it was never found associated with thermal stress. To our knowledge, no data on the thermal regulation of mRNA expression of ArgK has been reported to date. Its regulation has mostly been studied at a protein level and this is the only phosphagen kinase known in crustaceans and mollusks. ArgK is indeed regulated in crustaceans and mollusks under hypoxia $[53,54]$. In the crustacean Marsupenaeus japonicus, the up-regulation of ArgK under hypoxia may represent a provision for oxygen recovery after a short period of hypoxia [54]. The second metabolic enzyme is the cytosolic malate dehydrogenase, which catalyzes the dehydrogenation of malate $\left(\right.$ malate $+\mathrm{NADP}^{+} \leftrightarrow$ oxaloacetate $\left.+\mathrm{NADPH}+\mathrm{H}^{+}\right)$. It plays a major role in a number of metabolic pathways, including the malate-aspartate (or NADH) shuttle and the acetate shuttle active in lipogenesis, amino acid synthesis and gluconeogenesis. $\mathrm{cMDH}$ is an interesting candidate gene to study adaptation to temperature as this enzyme showed differences in the effects of temperature on kinetic properties in shallow water species $[7,55,56]$. Even though no cMDH mRNA expression has been reported in these studies, differences in protein properties strongly suggest a clear involvement of this key gene in response to temperature. The down-regulation of both $\operatorname{ArgK}$ and $\mathrm{cMDH}$ in $B$. thermophilus could lead to a decrease of mitochondrial respiration, leading to a lower ATP production, and resulting in the establishment of a global metabolic depression in response to temperature.

The cDNA coding for a HSP90 was found in the mussel SSH libraries. However, HSP90 displayed a down-regulation at $20^{\circ} \mathrm{C}$ when compared to $10^{\circ} \mathrm{C}$ suggesting that the process of protein re-naturation was probably over. HSP90 proteins have key roles in signal transduction, protein folding, protein degradation, and morphological evolution [57-59]. HSP90 is up-regulated in response to heat stress in Drosophila subobscura [60], the whitefly Bemisia argentifoli [61], and the flesh fly, Sarcophaga crassipalpis [62]. It is induced by thermal stress in the Goby fish but could also decrease in expression to a normal level during the acclimatization process [63]. In M. galloprovincialis, both HSP70 and HSP90 protein expression were shown to increase in response to long-term thermal challenge [44].

\section{Does temperature generate a stronger oxidative stress in mussels than in annelids?}

We identified several genes that are classically expressed in response to oxidative stress in the mussel libraries but not in the annelid libraries, suggesting a differential behavior of both species. Two main hypotheses can explain the presence of an oxidative stress: (1) a direct effect of temperature changes on lipid composition or (2) variations of the oxygen concentration during experiments. In the first hypothesis, temperature directly affects cells by modifying membrane composition through replacement of unsaturated fatty acids at low temperatures towards saturated fatty acids at high temperatures [64], and secondly by inducing apoptosis via activation of the sphingomyelin pathway that leads to the process of lipid peroxidation [65]. Many biological structures, such as enzymes and lipid bilayer membranes, depend on a particular degree of molecular instability or fluidity, which is directly affected by temperature. In the particular case of our experimented hydrothermal species, lipids of cell membrane bilayers must be both fluid and structurally coherent to form a 
functional membrane, a characteristic very sensitive to temperature change [2]. Lipid peroxyl radicals (LPO) are the result of a reaction between lipid and oxygen and are known to damage cells by changing the fluidity and permeability of the membrane and/or by directly damaging DNA and other intracellular molecules, such as proteins [66]. As a consequence of the lipid peroxidation process, superoxide anion radicals can be produced. Lipid peroxidation has been studied in hydrothermal vent mussels and high levels of LPO were detected in B. azoricus in response to a strong effect of environmental heavy metal concentrations [67]. Recently, heavy metal stresses, such as copper exposure, or changes in hydrostatic pressure were also shown to produce LPO in B. azoricus [68]. Fatty acid desaturases are very important during the process of fatty acid metabolism that contributes to the structural and functional maintenance of biological membranes in living organisms. The down-regulation of $\Delta 5$-desaturase mRNA expression of $B$. thermophilus exposed to $20^{\circ} \mathrm{C}$ is consistent with a modification of membrane lipid content. We also identified a gene encoding SPARC, which is more expressed in mussels incubated at $10^{\circ} \mathrm{C}$ when compared to those exposed to $20^{\circ} \mathrm{C}$. SPARC is classically known to modulate cellular interaction with the extracellular matrix through interactions with proteins such as laminins and collagen $[69,70]$. SPARC was also shown to be up-regulated in response to heat-shock and other stresses [71,72]. SPARC also possesses a chaperone-like activity in vitro suggesting its involvement in stress response [73]. Its down-regulation at $20^{\circ} \mathrm{C}$ is coherent with results observed by previous authors and could reflect a strong disorder in membrane composition due to the high temperature.

In the second hypothesis, the generation of reactive oxygen species (ROS) as side products of electron transfer during aerobic metabolism [74] can explain the regulation of genes encoding protective proteins in mussels. Here, oxidative stress can be due to the experimental conditions used where sea-water was at a low-oxygen concentration (below $120 \mu \mathrm{M}$ ) associated with a consumption by animals and the effect of temperature. In the presence of low oxygen concentration or anoxic conditions, organisms use anaerobic metabolism and annelids and mollusks are able to use more efficient mitochondrial pathways of fermentation [75-77]. Under normal physiological conditions, anaerobic metabolism produces free radicals, and cells tend to maintain a balance between generation and neutralization of ROS. When organisms are subjected to xenobiotics, temperature increase or anoxia events, the generation of ROS can exceed the scavenging capacity [78]. All organisms possess their own cellular antioxidant defense system, composed of both enzymatic (superoxide dismutase, catalase and glutathione peroxidases) and non-enzymatic (glutathione, vita- mins...) components. Glutathione peroxidases (GPx), that have protective roles against oxidative stress, have been identified in $B$. thermophilus libraries suggesting an oxidative stress as a direct or indirect result of temperature challenge. Surprisingly, GPx expression is lower in mussels exposed to $20^{\circ} \mathrm{C}$ than those exposed to $10^{\circ} \mathrm{C}$ despite the fact that oxidative stress is supposed to be stronger at $20^{\circ} \mathrm{C}$, supporting the idea that $B$. thermophilus is no longer able to regulate expression of oxidative stress related genes. We also identified a gene encoding a myc homolog which is up-regulated at $20^{\circ} \mathrm{C}$ compared to $10^{\circ} \mathrm{C}$-exposed mussels. This protein belongs to a transcription factor family and is involved in the cell division control. Myc and its binding partners regulate the expression of a large number of genes that regulate diverse functions, including protein synthesis, apoptosis, and DNA and energy metabolism [79-81]. Generally speaking, over-expression of a myc-homolog enhances apoptosis by acting as a transcription repressor $[82,83]$. In bivalves, c-myc has previously been shown to be up-regulated by hypoxia [49] and hydrocarbon stresses [46]. Identification of c-myc in mussel exposed to $20^{\circ} \mathrm{C}$ seems to be indicative of the very poor biological condition of the $20^{\circ} \mathrm{C}$-exposed individuals and thus in accordance with the hypothesis of a low tolerance of $B$. thermophilus to extended exposure to high temperature.

A gene that is involved in adenosine metabolism, and that has previously been shown to be regulated in response to hypoxia, has also been found in both mussel and annelid libraries. This enzyme called $S$-adenosylhomocysteinase hydrolase (SAHH, EC 3.3.1.1) catalyses the reversible hydrolysis of $S$-adenosylhomocysteine to form homocysteine and adenosine [84]. AdenosineMethionine/AdenosineHomocysteine turnover is believed to play a critical role in methionine metabolism and the regulation of biological methylation processes. Tissue hypoxia induces a variety of functional changes, including enhanced transcriptional activity associated with high transmethylation activity (e.g. mRNA cap methylation) in the nucleus. Disturbance in DNA methylation pattern has previously been observed in response to various stressors, such as heavy metals, as a consequence of toxicity $[85,86]$. In both our species, the mRNA expression of this gene is lower in animals exposed to $20^{\circ} \mathrm{C}$ than to $10^{\circ} \mathrm{C}$. This regulation of SAHH mRNA expression supports the hypothesis of a response to a direct or indirect oxidative stress. Presence of SAHH in response to temperature also illustrates the importance of methylation processes as a response to temperature increase. Generally speaking, a strong DNA methylation leads to a decrease or an inactivation of gene expression. Methylation processes regulation could be an interesting type of response to temperature in hydrothermal species. 


\section{Specific responses to temperature in mussels and annelids} In the mussel libraries, we interestingly identified three down-regulated genes at $20^{\circ} \mathrm{C}$ that are involved in foot activity (foot protein and pedal retractor muscle myosin) and byssus activity (adhesive plaque matrix protein). These results are in sharp contrast with previous studies performed on the brackish-water mussel, Mytilopsis leucophaeata that showed an increase in foot activity index and byssus thread production in response to thermal challenge [87]. Authors demonstrated that both foot activity and byssus production were higher when temperature increased from 4 to $20^{\circ} \mathrm{C}$, remained stable between 20 and $28^{\circ} \mathrm{C}$, and then strongly decreased beyond $28^{\circ} \mathrm{C}$. This species commonly lives in a range of temperatures comprised between $4^{\circ} \mathrm{C}$ (winter) and $20^{\circ} \mathrm{C}$ (summer). Mussels of the genus Bathymodiolus are able to change location when the conditions are not adequate [88]. This can be viewed as an escape response in the presence of stress factors. They also probably use this mobility to optimize their position in the hydrothermal fluid in order to acquire the sulfide (and/or methane for some species) they need to feed their symbionts. The decrease of the expression of genes encoding proteins related to mobility in mussels exposed at $20^{\circ} \mathrm{C}$, again reflects the poor physiological condition of these individuals, since mussels usually live in colder waters ( 4 to $14^{\circ} \mathrm{C}$ ).

In the annelid SSH libraries, we identified several genes encoding various extracellular globin chains (B1, A2 and B2), one intracellular globin and also three linkers called linker L1, linker L2 and linker LY. These results illustrate a strong involvement of respiratory pigment in general and in particular of the hexagonal bilayer hemoglobin (HBL$\mathrm{Hb}$ ) in response to temperature in this species. In Alvinellidae, respiratory gas transport is performed by the blood and the coelomic fluid, and three main types of globins are present: non-circulating in the cytoplasm, circulating and intracellular in the coelom, and extracellular in the vascular system [24]. Earlier work reported the temperature effect on both the function and the stability of Hbs in the annelid Alvinella pompejana, under atmospheric pressure and for temperatures ranging from $10^{\circ} \mathrm{C}$ to $40^{\circ} \mathrm{C}$. These Hbs are able to maintain a capacity to reversibly bind oxygen in vitro over this range. At $50^{\circ} \mathrm{C}$, the Hbs are oxidized and aggregated during the de-oxygenation and the re-oxygenation [89]. These results are in agreement with the hypothesis that annelids, even if they are able to withstand a strong thermal stress [25], are nonetheless unable to sustain high temperature for a long time [24]. Because $P$. pandorae lives in a relatively cold environment compared to other Paralvinella species, such as $P$. sulfincola, and probably do not experience very high temperatures, the involvement of Hbs in temperature response could be the result of several processes and not only driven by $\mathrm{Hb}$ thermostability properties. We observed a strong increase of mRNA encoding extracellular Hb subu- nits in individuals exposed to $20^{\circ} \mathrm{C}$ and conversely, a decrease of intracellular subunit mRNA expression. It has been suggested that extracellular Hbs were preferentially involved in oxygen uptake and transport, while intracellular Hbs acted as an oxygen reserve for the worm and potentially returned oxygen to the extracellular $\mathrm{Hb}$ [90]. Because oxygen availability decreases with temperature, Paralvinella increased their extracellular $\mathrm{Hb}$ production to optimize the oxygen uptake and transport. At the same time the intracellular $\mathrm{Hb}$ was down-regulated, possibly to avoid the release of $\mathrm{O}_{2}$ to the tissue since the worms experienced hot temperature but not hypoxia). We also observed an opposite regulation in the expression of linkers L1 and L2 in P. pandorae in response to thermal stress suggesting a possible rearrangement of the linker composition of the HBL-Hb molecule under temperatureinduced oxidative stress. Very few studies have dealt with the linker function and regulation at a transcriptional level. In the Earthworm Lumbricus terrestris, linkers have been shown to exhibit a superoxide dismutase activity conferring a protection against superoxide ions for HBL$\mathrm{Hb}$ molecules [91]. Linkers of the thermally-stressed alvinellids may therefore have been mobilized as an active defense against newly-produced ROS.

In the $P$. pandorae library, we also identified one gene encoding a secreted nidogen domain protein that showed a strong down-regulation at $20^{\circ} \mathrm{C}$. Secreted nidogen domain protein, also known as entactin, belongs to basement membrane proteins. These membranes are made of type IV collagens and laminins, both of which exist as various isoforms in animals $[92,93]$. These proteins are celladhesive and form networks that confer mechanical stability to the basement membranes. Other ubiquitous basement membrane components are the proteoglycan perlecan and nidogen/entactin. Previous in vitro experiments showed that recombinant nidogen-1 interacted through different binding sites with the three main basement membrane components (laminin, collagen IV, and perlecan), and mediated the formation of ternary complexes between laminin and collagen IV [94]. These results therefore suggest that secreted nidogen domain protein is a key component of alvinellid basement membranes assembly, connecting the laminin and collagen networks, and integrating other basement membrane components as previously reported by Timpl and Brown [93]. We suggest that temperature (and/or pressure) above normal could induce strong changes in the membrane composition of the worms and therefore increase interactions between secreted nidogen domain protein, collagen and other membrane protein in order to readjust porosity/permeability. Other proteins that are thought to partially play a role in membrane component modeling have also been characterized. We identified a Ras-associated binding 7 (Rab 7) protein belonging to the Rab family. These are small GTPases of the Ras superfamily that con- 
tinuously cycle between the cytosol and different membranes. The Rab family appears to be essential for the regulation of intracellular membrane traffic in mammalian cells. Rab proteins are anchored to the cytoplasmic surface of specific intracellular membrane compartments via the geranyl-geranyl group that is post-translationally added to the C-terminal cysteines and is important for their function [95]. Each Rab protein regulates one (or more) specific step of intracellular membrane traffic in eukaryotic cells, probably by assembling the general tethering/docking/fusion machinery [96]. Moreover, several lines of evidence suggest an involvement of Rab proteins in actin- and microtubule- based processes [97]. Rab7, a member of the Rab family small G proteins, has been shown to regulate intracellular vesicle traffic to late endo- some/lysosome and lysosome biogenesis, but the exact roles of Rab7 are still undetermined [98,99]. Accumulating evidence suggests that each Rab protein has multiple target proteins that function in the exocytic/endocytic pathway. Because no studies showing how temperature could affect Rab 7 expression, its down regulation observed in $P$. pandorae by temperature remains difficult to explain but could be associated with results observed for nidogen protein.

\section{Conclusion}

Our results indicate that the mussels and the worms did not cope with temperature in the same way. While the mussel $B$. thermophilus seems to show a general metabolic depression (strong decrease of mRNA expression for

Table 5: Primer sequences used in real-time PCR expression analysis for B. thermophilus SSH libraries validation

\begin{tabular}{|c|c|}
\hline Genes & Primer sequences \\
\hline \multirow[t]{2}{*}{ Elongation factor beta } & For: 5' GATCTTAAAAGTAAAGCTGGTCAGCAAGC 3' \\
\hline & Rev: 5' AACAAATCAAAATCATCATCATCACCGCC 3' \\
\hline \multirow[t]{2}{*}{ Ribosomal protein L3 } & For: 5' AGATATATCGTATTGGAGAGGGATACCACACC 3' \\
\hline & Rev: 5' GCTGTTGCATCCTTCTTCAATGGACCCAT 3' \\
\hline \multirow[t]{2}{*}{ Foot protein } & For: 5' AATAATGGTAAATGTGTTGCTAATGGCTA 3' \\
\hline & Rev: 5' CCGTATCCCCTTCTACAACATCTACCGCC 3' \\
\hline \multirow[t]{2}{*}{ Pedal retractor myosin } & For: 5' AGAACCGACGAATTGGAAGAGGCCAAGAG 3' \\
\hline & Rev: 5' AACAATTCAGCAGAGTAACTGCGGGCCTC 3' \\
\hline \multirow[t]{2}{*}{ Adhesive plaque matrix } & For: 5' AAAAGATGTGAAGTAAACAGATGCAGCCCA 3' \\
\hline & Rev: 5' CCGTATCCCCTTCTACAACATCTGCCGCC 3' \\
\hline \multirow[t]{2}{*}{ Actin } & For: 5' ACGCGGGTCAGGGTCGGACGTAGCCACGC 3' \\
\hline & Rev: 5' ATGGAGATCAGACGGAGATGGTCCTCCTC 3' \\
\hline \multirow[t]{2}{*}{ Adenosylhomocysteinase } & For: 5' GTAAATCTTGGTTGTGCTCATGGTCATCC 3' \\
\hline & Rev: 5' GATTTGAATGGTCCTTCTTTAGGTAGACC 3' \\
\hline \multirow[t]{2}{*}{ Cyclophilin S } & For: 5' TTGAATAAAGCCAGATGGATGGATGGAAA 3' \\
\hline & Rev:5' AAATCTTCATCGCTAGCTGCTTGTGCTTC 3' \\
\hline \multirow[t]{2}{*}{ Arginine kinase } & For: 5' ATGGGTGAAGTAGCAGAATTGTGGGCTAA 3' \\
\hline & Rev: 5' TCACATGCATACAATCCGACTCCGCT 3' \\
\hline \multirow[t]{2}{*}{ Glutathione peroxidase } & For: 5' ATGGGCATAAACTTGGGAGACATTTT 3' \\
\hline & Rev: 5' CCTAATTCTGTTGTACAAACAGGGGTATA 3' \\
\hline \multirow[t]{2}{*}{ BthermESTI } & For: 5' AGTGACTTCACAACTGCCCGTATGTGGAA 3' \\
\hline & Rev:5' TTGGTGCACATCATCAAGAAGGAGAGTAT 3' \\
\hline \multirow[t]{2}{*}{ Kalicludine } & For: 5' CCATGCAATGAAGATTGTCTTTTGCCAAA 3' \\
\hline & Rev: 5' TTTGGCAAAAGACAATCTTCATTGCATGG 3' \\
\hline \multirow[t]{2}{*}{ Defensin } & For: 5' ATGTTCAAAGTAACTTTGTTCTTCGTTGG 3' \\
\hline & Rev: 5' TACGATCTGCAGTGACACACGTTATG 3' \\
\hline \multirow[t]{2}{*}{ SPARC } & For: 5' AACGCAGACGACCACCGTACAGACGC 3' \\
\hline & Rev: 5' TATGCATCACACTTGTCTGTAATGTCAACC 3' \\
\hline \multirow[t]{2}{*}{$\Delta 5$-desaturase } & For: 5' AACGACTGGTTTACAGGGCATCTAAA 3' \\
\hline & Rev: 5' TTTAGATGCCCTGTAAACCAGTCGTT 3' \\
\hline \multirow[t]{2}{*}{ Carbonic anhydrase-2 } & For: 5' GATGACAAGGAAGGATCTGAGCACACTCT 3' \\
\hline & Rev: 5' AGAGTGTGCTCAGATCCTTCCTTGTCATC 3' \\
\hline \multirow[t]{2}{*}{ HSP90 } & For: 5' ATGCCTGAACCTGAAACAACTATGGATGA 3' \\
\hline & Rev: 5' GAATACATCTGGGAATCTGCAGCTGGTGG 3' \\
\hline \multirow[t]{2}{*}{ Myc homolog } & For: 5' TCTGTTTATGATGCCTGGGTCACTCC $3^{\prime}$ \\
\hline & Rev: 5' GGAGTGACCCAGGCATCATAAACAGA 3' \\
\hline \multirow[t]{2}{*}{ Cytosolic malate dehydrogenase } & For: 5' ATGGCAGTTCCTTCAGATGGATCTTA 3' \\
\hline & Rev: 5' CAATACACAAAAACAGACACTGTATACAT 3' \\
\hline \multirow[t]{2}{*}{ Techylectin 5A } & For: 5' GGATATCAGGGTAATGCAGGAGATGC 3' \\
\hline & Rev: 5' GCATCTCCTGCATTACCCTGATATCC 3' \\
\hline
\end{tabular}


numerous genes), possibly due to maladaptation and cell disorders when temperature increased, the annelid P. pandorae mainlydisplayed a strong regulation of the mRNA encoding subunits and linkers of respiratory pigments and some proteins involved in membrane constitution. In both cases, these regulations seem to be partly due to a possible cellular oxidative stress induced by temperature increase $\left(10^{\circ} \mathrm{C}\right.$ to $\left.20^{\circ} \mathrm{C}\right)$. The large number of unknown sequences makes definitive conclusions difficult. The data collected may contain a number of candidate genes regulated by temperature that require annotation and functional characterization before meaningful interpretation of temperature adaptation of both $P$. pandorae and $B$. thermophilus is possible. New tools, such as microarrays will help evaluate the expression and characterization of these genes. This work will serve as a starting point for studying the transcriptomic response of hydrothermal mussels and annelids in future experiments in response to thermal stress at various conditions of exposure duration and thermal level.

\section{Methods}

\section{Animal sampling and treatment}

Specimens of both the hydrothermal vent mussel Bathymodiolus thermophilus (67.8 $\pm 30 \mathrm{~mm}$ in length) and the annelid worm Paralvinella pandorae irlandei $(\leq 10 \mathrm{~mm}$ in length) were collected together from the Oasis site $\left(17^{\circ} 25.42 \mathrm{~S}, 113^{\circ} 12.28 \mathrm{~W}\right)$ on the East Pacific Rise during the BIOSPEEDO cruise [100] by using the telemanipulated arm of the submersible Nautile. The individuals were collected in a cold zone associated with weak diffuse flow $\left(<10^{\circ} \mathrm{C}\right)$. Once on board the ship, animals were immediately transferred from the insulated collection basket to the pressurized aquaria IPOCAMP ${ }^{\text {тм }}$ (Incubateur Pressurisé pour l'Observation et la Culture d'Animaux Marins Profonds [101]) under an in situ pressure of 260 bars. Indeed, several studies showed that experiments conducted on mussels at atmospheric pressure lead to a global increase of stress parameters (lipid peroxidation, anti-oxidant enzymes activity, DNA damage) and to a limitation of stress response capacity $[14,23,102]$. One group of 5 mussels and 20 worms was placed at $10^{\circ} \mathrm{C}$, and another group at $20^{\circ} \mathrm{C}$, inside two different pressure vessels for 43 hours. The pressure vessels were operated in a flow-through mode (20 L/hour) for the first 3 hours, and then isolated. Every 15 hours, seawater was re-circulated for 3 hours, until the end of the incubation. When in flowthrough configuration, the pressure aquaria were fed with sea-water aerated with a low-oxygen (8\%) air mixture. Therefore, oxygen levels during the experiments were at a

Table 6: Primer sequences used in real-time PCR expression analysis for $P$. pandorae irlandei SSH libraries validation.

\begin{tabular}{|c|c|}
\hline Genes & Primer sequences \\
\hline \multirow[t]{2}{*}{ Intracellular hemoglobin } & For: 5' CTTGCCGATAACATTACTGCTGTTCGAGG 3' \\
\hline & Rev: 5' TCGGCATCACCCGCCTTCTCCGCTACGTC 3' \\
\hline \multirow[t]{2}{*}{ Hemoglobin A2c } & For: 5' GTTCTGATCATAATCGCTGTCTGTCTGG 3' \\
\hline & Rev: 5' TGTAGAAGCTGGGCATTCAGCGTGTCGGG 3' \\
\hline \multirow[t]{2}{*}{ Linker LI } & For: 5' ATCATGGCAGGCCTGGTGGCACTCGCCAT 3' \\
\hline & Rev: 5' TCTGATCCGTCATGACAGTCGTTAGCACC 3' \\
\hline \multirow[t]{2}{*}{ Linker L2 } & For: 5' ATGGTTGACGATGAGATGGACTTGATGGA 3' \\
\hline & Rev: 5' ATCTTATAGCTGTCTATAGTAACCCG 3' \\
\hline \multirow[t]{2}{*}{ Hemoglobin B2 } & For: 5' CTGGATCATCTCGGCCGTCAGCATGTTGT 3' \\
\hline & Rev: 5' GTGTGGTCGAGACGCGTTGCTCGGTCCGC 3' \\
\hline \multirow[t]{2}{*}{ PpandEST 2} & For: 5' CAACCATGTGCCTACTTTACCTTGTTCAG 3' \\
\hline & Rev: 5' AAGAACAGCTGCTGCAGAATATCTCCCAC 3' \\
\hline \multirow[t]{2}{*}{ Xylan endohydrolase } & For: 5' GAGATGGAAGAGAGAAATCCAGATTGGCT 3' \\
\hline & Rev: 5' AGTTTCGCCTTCGAGTCACCGCTGTAGGC 3' \\
\hline \multirow[t]{2}{*}{ Rab 7} & For: 5' CTTATTCAAGCTAGCCCACGAGATCCAGA 3' \\
\hline & Rev: 5' CAACTCTCCGCTGAAGTCTTCGCCCGGTC 3' \\
\hline \multirow[t]{2}{*}{ Adenosylhomocysteinase } & For: 5' ATTGTGTGCAATATTGGACATTTTGACTGTGA 3' \\
\hline & Rev: 5' AGACCTAAATAGCCAGCCTGGTCATCTGA 3' \\
\hline \multirow[t]{2}{*}{ Chymotrypsin } & For: 5' ACAGAGGTCGAATACGAGGTGATGACAAT 3' \\
\hline & Rev: 5' ATGCCACCTGAGCTAAGAGTTCCCCATCC 3' \\
\hline \multirow[t]{2}{*}{ PpandEST I } & For: 5' GAAGCTGACCTAGCTTACGCCGGTCTGAA 3' \\
\hline & Rev:5' TAGGGCTCGAGCGGCCGCCCGGGCAG 3' \\
\hline \multirow[t]{2}{*}{ Ribosomal protein SI6 } & For: 5' GCTGTTGCTCACTGCAAACAGGGCAAAGGT 3' \\
\hline & Rev: 5' TTGATCTCTTTCTTTGATGCTTCGTCGTC 3' \\
\hline \multirow[t]{2}{*}{ Nidogen secreted domain protein } & For: 5' CAATGCAAGTATTGGCCATGGCATGGTAG 3' \\
\hline & Rev: 5' ACCCAGCGTCCTGCTTTGGCGACGTTACT 3' \\
\hline \multirow[t]{2}{*}{ Lipid binding protein } & For: 5' TTCAACATGTCTCAATTGAATGGGAAATGGAA 3' \\
\hline & Rev: 5' TCCAGGCCCGTTTCGTTCACCTCGATACG 3' \\
\hline
\end{tabular}


maximum value of about $120 \mu \mathrm{M}$ during circulation periods, and obviously decreased when the vessels were isolated, due to oxygen consumption by experimented animals. No mortality was observed at the end of the experiments, and samples of mussels (pool of gills, foot, mantle, adductor muscle) and worms (whole organisms) were collected and immediately frozen in liquid nitrogen until use.

\section{RNA extraction}

Total RNA was extracted from the gill, adductor muscle, mantle and foot of 5 thermally-challenged mussels, and 6 whole worms with the Trizol Reagent according to the manufacturer's instructions. Total RNAs extracted from the different tissues were pooled and poly( $\mathrm{A}+)$ mRNA was isolated using the PolyATtract ${ }^{\circledR} \mathrm{mRNA}$ Isolation System (Promega, Madison, WI, USA) according to the manufacturer's instructions.

\section{Suppression subtractive hybridization}

Both forward (individuals incubated at $10^{\circ} \mathrm{C}$ versus individuals incubated at $20^{\circ} \mathrm{C}$ ) and reverse (individuals incubated at $20^{\circ} \mathrm{C}$ versus individuals incubated at $10^{\circ} \mathrm{C}$ ) subtracted libraries were produced from $2 \mu \mathrm{g}$ of mRNA extracted from experimented mussels and worms. First and second strand cDNA synthesis, RsaI endonuclease enzyme digestion, adapter ligation, hybridization, and PCR amplification were performed as described in the PCR-select cDNA subtraction kit manual (Clontech, Palo Alto, CA, USA).

\section{Cloning and sequencing}

The differentially expressed PCR products were ligated into a pGEM-T vector (Promega, Madison, WI, USA) and 200 white colonies per library were cultured in LB medium supplemented with $100 \mathrm{mg} / \mathrm{L}$ ampicillin. Plasmids were then extracted using an alkaline lysis plasmid minipreparation, and sequenced using the Big Dye Terminator V3.1 Kit (Perkins-Elmer) and run on an AB3100 sequencer (Applied Biosystems Perkins-Elmer).

\section{Sequence analysis and homology search}

Chromatograms obtained after sequencing were treated with the Seqclean software (TGIR, the Institute for Genomic Research, Rockville, MD, USA) to remove vector and adaptors sequences. Cluster and contigs were then formed on each library sequence set. BLAST analyses of the sequences were performed on the NCBI server. The sequences were analyzed for homology with known sequences in databases using the BlastX and BlastN programs http://www.ncbi.nlm.nih.gov/BLAST/.

\section{Validation of differential expression by real-time PCR}

A validation step of the differentially expressed genes identified in B. thermophilus and P. pandorae SSH libraries was carried out using real-time PCR and total RNA samples used for the SSH construction. For each sample, $5 \mu \mathrm{g}$ of total RNA were submitted to reverse transcription using oligo-dT anchor primer (5'-GAC CAC GCG TAT CGA TGT CGA $\left.\mathrm{CT}_{(16)} \mathrm{V}-3^{\prime}\right)$ and M-MLV reverse transcriptase (Promega, Madison, WI, USA). Amplification of 20 genes isolated in the SSH libraries was carried out on the cDNA from both 10 and $20^{\circ} \mathrm{C}$ exposed mussel samples and 14 genes were amplified on pool of cDNA from samples of annelid exposed to both 10 and $20^{\circ} \mathrm{C}$. The real-time PCR assay was performed in triplicate with $4 \mu \mathrm{L}$ cDNA $(1 / 20$ dilution) in a final volume of $10 \mu \mathrm{L}$ using the Chromo $4^{\mathrm{TM}}$ System (BioRad). The concentrations of the reaction components were as follows: $1 \times$ ABsolute $^{\mathrm{TM}}$ QPCR SYBR $^{\circledast}$ Green mix (ABgene, UK) and $70 \mathrm{nM}$ of each primer (Tables 5 and 6). The $18 \mathrm{~S}$ ribosomal DNA was amplified as an endogenous PCR control, under the same amplification conditions using sense (5'-AAG GGC AGG AAA AGA AAC TAA C-3') and antisense (5'-GTT TCC CTC TAA GTG GTT TCA C-3') primers. The amplification was carried out as follows: initial enzyme activation at $94^{\circ} \mathrm{C}$ for $15 \mathrm{~min}$, then 45 cycles of $94^{\circ} \mathrm{C}$ for $15 \mathrm{sec}$ and $60^{\circ} \mathrm{C}$ for $1 \mathrm{~min}$. A dissociation curve was generated and PCR efficiency (E) was estimated for each primer pair by using a serial dilution of reverse transcription products. Standard curves were generated for each primer pair and $\mathrm{E}$ was calculated using the formula $\mathrm{E}=10^{(-1 / \text { slope })}-1$. All primer pairs tested generated a single peak in the dissociation curve with a PCR efficiency estimated between 95 and 100\%. Relative quantification (RQ) of each gene expression was calculated according to comparative CT method using the formula: $\mathrm{RQ}=$ exponential $\left(2^{-\Delta \Delta \mathrm{CT}}\right)$ with $\Delta \Delta \mathrm{CT}=\Delta \mathrm{CT}\left(10^{\circ} \mathrm{C}\right)$ $-\Delta \mathrm{CT}\left(20^{\circ} \mathrm{C}\right)$ and $\Delta \mathrm{CT}\left(10^{\circ} \mathrm{C}\right)=\mathrm{CT}\left(\right.$ gene $\mathrm{X}$ in the $10^{\circ} \mathrm{C}$ sample) - CT(18S) and $\Delta \mathrm{CT}\left(20^{\circ} \mathrm{C}\right)=\mathrm{CT}$ (gene $\mathrm{X}$ in the $20^{\circ} \mathrm{C}$ sample) - CT(18S); $18 \mathrm{~S}$ ribosomal DNA being used as the endogenous control.

\section{Competing interests}

The authors declare that they have no competing interests.

\section{Authors' contributions}

IB carried out gene amplification and library screening, the sequence analysis and drafted the manuscript. AT produced cDNA libraries and helped to draft the manuscript. DJ and BS sampled the experimental animals, designed and performed the experimental work on board of the ship N/O L'Atalante using the pressurized vessels IPOCAMP and helped to draft the manuscript. DM helped to draft the manuscript. All authors read and approved the final manuscript.

\section{Acknowledgements}

We wish to thank the captain and crew of the NO L'Atalante, the crew of the Nautile submersible, and the chief scientist of the BioSpeedo cruise. We also thank the personnel of the Ouest-Génopôle sequencing platform in Roscoff, particularly Morgan Perennou. We would like to thank Stéphane 
Hourdez for English editing. We thank the Marine Genomics Europe EDD Node. This work is part of the ANR project "AdapAlvinSTres" (\# ANR-05 BLAN-0407-02) and was also supported by a grant from the Région Bretagne (PRIRE "Amethyst").

\section{References}

I. Somero GN: Proteins and temperature. Annu Rev Physiol 1995, 57:43-68.

2. Hochachka PW, Somero GN: Biochemical adaptation Princeton: Princeton University Press; 1984.

3. Hochachka PW, Somero GN: Biochemical adaptation New York: Oxford University Press; 2002

4. Eanes WF: Analysis of selection on enzyme polymorphisms. Ann Rev Ecol Syst 1999, 30:301-326.

5. Watt WB, Dean AM: Molecular-functional studies of adaptive genetic variation in prokaryotes and eukaryotes. Annu Rev Genet 2000, 34:593-622.

6. Somero GN: Adaptation of enzymes to temperature: searching for basic "strategies". Comp Biochem Physiol B Biochem Mol Biol 2004, I 39:321-333.

7. Fields PA, Rudomin EL, Somero GN: Temperature sensitivities of cytosolic malate dehydrogenases from native and invasive species of marine mussels (genus Mytilus): sequence-function linkages and correlations with biogeographic distribution. J Exp Biol 2006, 209:656-667.

8. Von Damm KL: Seafloor hydrothermal activity: black smoker chemistry and chimneys. Ann Rev Earth Planet Sci 1990, 1 8:173-204.

9. Chevaldonné $P$, Desbruyères $D$, Le Haître $M$ : Time-series of temperature from three deep-sea hydrothermal vent sites. Deep Sea Res 1991, 38:1417-|430.

10. Sarrazin J, Juniper SK, Massoth GJ, Legendre P: Physical and chemical factors influencing species distributions on hydrothermal sulfide edifices of the Juan de Fuca Ridge, northeast Pacific. Mar Ecol Prog Ser 1999, 190:89- I I2.

II. Shank TM, Fornari DJ, Von Damn KL, Lilley MD, Haymon RM, Lutz RA: Temporal and spatial patterns of biological community development at nascent deep-sea hydrothermal vents (950'N, East Pacific Rise). Deep Sea Res II 1998, 45:465-5 I 5.

12. Sarrazin J, Juniper SK: Biological characteristics of a hydrothermal edifice mosaic community. Mar Ecol Prog Ser 1999, 185: I-19.

13. Luther GW, Rozan TF, Martial T, Nuzzio DB, Di Meo C, Shank TM, Lutz RA, Cary SC: Chemical speciation drives hydrothermal vent ecology. Nature 200I, 410:8I3-8I6.

14. Company R, Serafim A, Cosson RP, Fiala-Médioni A, Camus L, Colaço A, Serrão-Santos R, Bebianno MJ: Antioxidant biochemical responses to long-term copper exposure in Bathymodiolus azoricus from Menez-Gwen hydrothermal vent. Sci Total Environ 2008, 389:407-4I7.

15. Hardivillier Y, Denis F, Demattei MV, Bustamante P, Laulier M, Cosson R: Metal influence on metallothionein synthesis in the hydrothermal vent mussel Bathymodiolus thermophilus. Comp Biochem Physiol C Toxicol Pharmacol 2006, I 43G:321-332.

16. Bettencourt R, Roch P, Stefanni S, Rosa D, Colaço A, Santos RS: Deep sea immunity: unveiling immune constituents from the hydrothermal vent mussel Bathymodiolus azoricus. Mar Environ Res 2007, 64:108-127.

17. Tanguy A, Bierne N, Saavedra C, Pina B, Bachere E, Bonhomme F, Boudry P, Boulo V, Boutet I, Dossat C, Favrel P, Huvet A, Jollivet D, Klages S, Lapegue S, Moal J, Moraga D, Reinhard R, Samain JF, Zouros $E$, Canario $A$ : Increasing genomic information in Bivalves by new EST collections in four species. Gene 2008, 408:27-36.

18. Craddock C, Hoeh WR, Gustafson RG, Lutz RA, Hashimoto J, Vrijenhoek RJ: Evolutionary relationships among deep-sea mytilids (Bivalvia: Mytilidae) from hydrothermal vents and coldwater methane/sulphide. Mar Biol 1995, I 2 I:477-485.

19. Fiala-Médioni A, McKiness Z, Dando P, Boulegue J, Mariotti A, AlayseDanet A, Robinson J, Cavanaugh C: Ultrastructural, biochemical, and immunological characterization of two populations of a new species of mytilid mussel, Bathymodiolus azoricus, from the Mid-Atlantic Ridge: evidence for a dual symbiosis. Mar Biol 2002, I 4 I: 1035-1043.

20. Duperron S, Bergin C, Zielinski F, Blazejak A, Pernthaler A, McKiness ZP, DeChaine E, Cavanaugh CM, Dubilier N: A dual symbiosis shared by two mussel species, Bathymodiolus azoricus and Bathymodiolus puteoserpentis (Bivalvia: Mytilidae), from hydrothermal vents along the northern Mid-Atlantic Ridge. Environ Microbiol 2006, 8: |44I- 4447.

21. Ravaux J, Gaill F, Le Bris N, Sarradin PM, Jollivet D, Shillito B: Heatshock response and temperature resistance in the deep-sea vent shrimp Rimicaris exoculata. J Exp Biol 2007, 206:2345-2354.

22. Cottin D, Ravaux J, Léger N, Halary S, Toullec JY, Sarradin PM, Gaill F, Shillito B: Thermal biology of the deep-sea vent annelid Paralvinella grasslei: in vivo studies. J Exp Biol 2008, 21 I:21 96-2204.

23. Pruski AM, Dixon DR: Toxic vents and DNA damage: first evidence from a naturally contaminated deep-sea environment. Aquat Toxicol 2003, 64:I-13.

24. Hourdez S, Weber RE: Molecular and functional adaptations in deep-sea hemoglobins. J Inorg Biochem 2005, 99:|30-14I.

25. Lee RW: Thermal tolerances of deep-sea hydrothermal vent animals from the northeast pacific. Biol Bull 2003, 205:98-10I.

26. Girguis PR, Lee RW: Thermal preference and tolerance of Alvinellids. Science 2006, 31 2:231.

27. Jollivet D, Desbruyeres D, Ladrat C, Laubier L: Evidence for differences in the allozyme thermostability of deep-sea hydrothermal vent polychaetes (Alvinellidae): a possible selection by habitats. Mar Ecol Prog Ser 1995, I 23:125-136.

28. Van Dover CL: Community structure of mussel beds at deepsea hydrothermal vents. Mar Ecol Prog Ser 2000, 230:137-I56.

29. Fisher CR, Childress JJ, Arp AJ, Brooks JM, Distel D, Favuzzi JA, Felbeck $\mathrm{H}$, Hessler R, Johnson KS, Kennicutt MC II, Macko SA, Newton A, Powell MA, Somero GN, Soto T: Microhabitat variation in the hydrothermal vent mussel, Bathymodiolus thermophilus, at the Rose Garden vent on the Galapagos Rift. Deep Sea Res 1988, 35:1769-1789.

30. Jollivet D: Specific and genetic diversity at deep-sea hydrothermal vents: an overview. Biodiv Conserv 1996, 5:1619-1653.

31. Jollivet D: Distribution et évolution de la faune associée aux sources hydrothermales profondes à $13^{\circ} \mathrm{N}$ sur la dorsale du Pacifique oriental: le cas particulier des polychètes Alvinellidae. Thèse de Doctorat NR, Université de Bretagne Occidentale, France; 1993.

32. Sanders BM: Stress proteins in aquatic organisms: an environmental perspective. Crit Rev Toxicol 1993, 23:49-75.

33. Feder ME, Hofmann GE: Heat-shock proteins, molecular chaperones, and the stress response: evolutionary and ecological physiology. Annu Rev Physiol 1999, 61:243-282.

34. Berger MS, Young CM: Physiological response of the cold-seep mussel Bathymodiolus childressi to acutely elevated temperature. Mar Biol 2006, 149:1397-1402.

35. Pruski AM, Dixon DR: Heat shock protein expression pattern (HSP70) in the hydrothermal vent mussel Bathymodiolus azoricus. Mar Environ Res 2007, 64:209-224.

36. Clarke A: Temperature and energetics: an introduction to cold ocean physiology. In Cold Ocean Physiology Edited by: Pörtner HO, Playle RC. Cambridge: Cambridge University Press; 1998:3-33.

37. Pörtner HO: Climate change and temperature-dependent biogeography: oxygen limitation of thermal tolerance in animals. Naturwissenschaften 200।, 88:। $37-146$.

38. Storey KB: Molecular mechanisms of metabolic arrest in molluscs. In Surviving Hypoxia: Mechanisms of Control and Adaptation Edited by: Hochachka PW, Lutz PL, Sick TJ, Rosenthal M, Thillart G. Boca Raton: CRC Press; 1993:253-27I.

39. Larade K, Storey KB: A profile of the metabolic responses to anoxia in marine invertebrates. In Cell and Molecular Responses to Stress Volume 3. Edited by: Storey KB, Storey JM. Amsterdam: Elsevier Press; 2002.

40. Peck LS: Ecophysiology of Antarctic marine ectotherms: limits to life. Polar Biol 2002, 25:3।-40.

4I. Sokolova IM, Pörtner HO: Metabolic plasticity and critical temperatures for aerobic scope in a eurythermal marine invertebrate (Littorina saxatilis, Gastropoda: Littorinidae) from different latitudes. J Exp Biol 2003, 206:195-207.

42. Peck LS, Conway LZ: The myth of metabolic coldadaptation: oxygen consumption in stenothermal Antarctic bivalves. In The evolutionary biology of the bivalvia Volume 177. Edited by: Harper EM, Taylor JD, Crame JA. Geol Soc Spec Publ London; 2000:44 I-445.

43. Peck LS: Prospects for survival in the Southern ocean: extreme temperature sensitivity of benthic species. $R$ Soc Spec Issue Antarct Sci 2005, 17:497-507. 
44. Anestis A, Lazou A, Pörtner HO, Michaelidis B: Behavioral, metabolic, and molecular stress responses of marine bivalve Mytilus galloprovincialis during long-term acclimation at increasing ambient temperature. Am J Physiol Regul Integr Comp Physiol 2007, 293:R9II-R92I.

45. Desbruyères D, Segonzac M, Bright M: Handbook of the deep-sea hydrothermal vent fauna 2nd edition. Linz, Austria: Denisia 18;; 2006.

46. Boutet I, Tanguy A, Moraga D: Response of the Pacific oyster Crassostrea gigas to hydrocarbon contamination under experimental conditions. Gene 2004, 329:|47-I57.

47. Tanguy A, Guo X, Ford SE: Searching for genes involved in host defense against Perkinsus marinus and Haplosporidium nelsoni infections in the eastern oysters. Gene 2004, 329:| $|2|-|3|$.

48. Tanguy A, Boutet I, Laroche J, Moraga D: Molecular identification and expression study of differentially regulated genes in the Pacific oyster Crassostrea gigas in response to pesticide exposure. FEBS J 2005, 272:390-403.

49. David E, Tanguy A, Pichavand K, Moraga D: Response of the Pacific oyster Crassostrea gigas to hypoxia exposure under experimental conditions. FEBS J 2005, 272:5635-5652

50. Strong SJ, Ellington WR: Isolation and sequence analysis of the gene for arginine kinase from the chelicerate arthropod, Limulus polyphemus : insights into catalytically important residues. Biochim Biophys Acta 1995, I 246: 197-200.

51. Wyss M, Smeitink J, Wevers RA, Wallimann T: Mitochondrial creatine kinase: a key enzyme of aerobic energy metabolism. Biochim Biophys Acta 1992, I 1 02: I 19-166.

52. Ellington WR: Evolution and physiological roles of phosphagen systems. Annu Rev Physiol 2001, 63:289-325.

53. Greenway SC, Storey KB: The effect of prolonged anoxia on enzyme activities in oysters (Crassostrea virginica) at different seasons. J Exp Mar Biol Ecol 1999, 242:259-272.

54. Abe H, Hirai S, Okada S: Metabolic responses and arginine kinase expression under hypoxic stress of the kuruma prawn Marsupenaeus japonicus. Comp Biochem Physiol A 2007, I 46:40-46.

55. Dahlhoff E, Somero GN: Pressure and temperature adaptation of cytosolic malate dehydrogenases of shallow- and deep-living marine invertebrates: Evidence for high body temperatures in hydrothermal vent animals. I Exp Biol 1991, I 59:473-487.

56. Dahlhoff E, Somero GN: Kinetic and structural adaptations of cytoplasmic malate dehydrogenases of eastern Pacific abalone (genus Haliotis) from different thermal habitats: Biochemical correlates of biogeographical patterning. J Exp Biol 1993, 185:137-150.

57. Nadeau K, Das A, Walsh CT: Hsp90 chaperonins possess ATPase activity and bind heat-shock transcription factors and peptidylprolyl isomerases. J Biol Chem 1993, 268:|479-| 487.

58. Jakob U, Buchner J: Assisting spontaneity - The role of $\mathbf{H s p 9 0}$ and small HSPs as molecular chaperones. Trends Biochem Sci |994, 19:205-21 |.

59. Rutherford S, Lindquist S: Hsp90 as a capacitor for morphological evolution. Nature 1998, 396:336-342.

60. Arbona M, Defrutos R, Tanguay RM: Transcriptional and translations study of the Drosophila subobscura hsp83 gene in normal and heat-shock conditions. Genome 1993, 36:694-700.

61. Salvucci ME, Stecher DS, Henneberry TJ: Heat shock proteins in whiteflies, an insect that accumulates sorbitol in response to heat stress. I Therm Biol 2000, 25:363-37I.

62. Rinehart JP, Denlinger DL: Heat-shock protein $\mathbf{9 0}$ is down-regulated during pupal diapause in the flesh fly, Sarcophaga crassipalpis, but remains responsive to thermal stress. Insect $\mathrm{Mol}$ Biol 2000, 9:64I-645.

63. Dietz T], Somero GN: Acclimatization in Eurythermal Goby Fishes (Genus Gillichthys) The Threshold Induction Temperature of the $90-\mathbf{k D a}$ Heat Shock Protein is Subject. Proc Natl Acad Sci USA 1992, 89:3389-3393.

64. Sinensky M: Homeoviscous adaptation-A homeostatic process that regulates the viscosity of membrane lipids in Escherichia coli. Proc Natl Acad Sci USA 1974, 7 I:522-525.

65. Mathias S, Pena LA, Kolesnick RN: Signal transduction of stress via ceramide. Ceramide also plays a pivotal role in stressinduced apoptosis. Biochem J 1998, 335:465-480.

66. Mattie MD, Freedman JH: Protective effects of aspirin and vitamin E ( $\alpha$-tocopherol) against copper- and cadmium-induced toxicity. Biochem Biophys Res Com 200I, 285:921-925.
67. Bebianno MJ, Company R, Serafima A, Camusb L, Cosson RP, FialaMedoni A: Antioxidant systems and lipid peroxidation in Bathymodiolus azoricus from Mid-Atlantic Ridge hydrothermal vent fields. Aquat Toxicol 2005, 75:354-373.

68. Company R, Serafim A, Bebianno MJ, Cosson R, Shillito B, Fiala-Médioni $A$ : Effect of cadmium, copper and mercury on antioxidant enzyme activities and lipid peroxidation in the gills of the hydrothermal vent mussel Bathymodiolus azoricus. Mar Environ Res 2004, 58:377-38।.

69. Sasaki T, Hohenester E, Gohring W, Timpl R: Crystal structure and mapping by site directed mutagenesis of the collagen binding epitope of an activated form of BM-40/SPARC/ osteonectin. EMBO J 1998, I 7:1625-1634.

70. Sweetwyne MT, Brekken RA, Workman G, Bradshaw AD, Carbon J, Siadak AW, Murri C, Sage EH: Functionnal analysis of the matricellular protein SPARC with novel monoclonal antibodies. J Histochem Cytochem 2004, 52:723-733.

7I. Kudo H, Hirayoshi K, Kitagawa Y, Imamura S, Nagata K: Two collagen-binding proteins, osteonectin and HSP47, are coordnately induced in transformed keratinocytes by heat and other stresses. Exp Cell Res 1994, 2 I 2:219-224.

72. Neri M, Descali-Cancedda F, Cancedda R: Heat shock response in cultured chick embryo chondrocytes. Osteonectin is a secreted heat-shock protein. Eur J Biochem 1992, 205:569-574.

73. Emerson RO, Sage EH, Ghosh JG, Clark JI: Chaperone-like activity revealed in the matricellular protein SPARC. I Cell Biochem 2006, 98:701-705.

74. Fridovich I: Oxygen toxicity: a radical explanation. J Exp Biol |998, 20 I: |203-|209.

75. Bryant C: Metazoan Life without Oxygen Suffolk: Chapman and Hall; I991.

76. Fenchel T, Finlay BJ: Ecology and Evolution in Anoxic Worlds New York: Oxford University Press; 1995.

77. Tielens AGM, Van Hellemond J]: The electron transport chain in anaerobically functioning eukaryotes. Biochim Biophys ActaBioenerg 1998, I 365:71-78.

78. Halliwell B, Gutteridge JMC: Free Radicals in Biology and Medicine Oxford: Clarendon Press; 1999.

79. Boon K, Caron HN, van Asperen R, Valentijn L, Hermus MC, van Sluis P, Roobeek I, Weis I, Voãute PA, Schwab M, et al.: N-myc enhances the expression of a large set of genes functioning in ribosome biogenesis and protein synthesis. EMBO / 200I, 20:1383-I393.

80. Schuldiner O, Benvenisty N: A DNA microarray screen for genes involved in C-MYC and N-MYC oncogenesis in human tumors. Oncogene 2001, 20:4984-4994.

8I. Watson JD, Oster SK, Shago M, Khosravi F, Penn LZ: Identifying genes regulated in a Myc-dependent manner. J Biol Chem 2002 , 277:3692I-36930.

82. Matsumura I, Tanaka $\mathrm{H}$, Kanakura $\mathrm{Y}$ : E2FI and c-Myc in cell growth and death. Cell Cycle 2003, 2:333-338.

83. To KW, Koshiji M, Hammer S, Huang LE: Genetic instability: the dark side of the hypoxic response. Cell Cycle 2005, 4:88I-882.

84. Dela Haba G, Cantoni GL: The enzymatic synthesis of S-adenosyl-Lhomocysteine from adenosine and homocysteine. J Biol Chem 1959, 234:603-608.

85. Liu J, Benbrahim-Tallaa L, Qian X, Yu L, Xie Y, Boos J, Qu W, Waalkes MP: Further studies on aberrant gene expression associated with arsenic-induced malignant transformation in rat liver TRL I 2 I 5 cells. Toxicol Appl Pharmacol 2006, 2 I 6:407-4I 5.

86. Bagnyukova TV, Luzhna LI, Pogribny IP, Lushchak VI: Oxidative stress and antioxidant defenses in goldfish liver in response to short-term exposure to arsenite. Environ Mol Mutagen 2007, 48:658-665.

87. Rajagopal S, Gaag M Van der, Velde G Van der, Jenner HA: Upper temperature tolerances of exotic brackish-water mussel, Mytilopsis leucophaeata (Conrad): An experimental study. Mar Environ Res 2005, 60:512-530.

88. Govenar B, Freeman M, Bergquist DC, Johnson GA, Fisher CR: Composition of a One-Year-Old Riftia pachyptila Community Following a Clearance Experiment: Insight to Succession Patterns at Deep-Sea Hydrothermal Vents. Biol Bull 2004, 207: $177-182$

89. Toulmond A, Slitine F, Frescheville J, Jouin C: Extracellular hemoglobins of hydrothermal vent annelids: structural and functional characteristics in three alvinellid species. Biol Bull 1990 , I 79:366-373. 
90. Hourdez S, Lallier FH, De Cian M, Green BN, Weber RE, Toulmond A: Gas Transfer System in Alvinella pompejana (Annelida Polychaeta, Terebellida): Functional Properties of IntracelIular and Extracellular Hemoglobins. Physiol Biochem Zool 2000, 73:365-373.

91. Liochev S, Kuchumov S, Vonogradov N, Fridovich I: Superoxide dismutase activity in the giant haemoglobin of the earthworm, Lumbricus terrestris. Arch Biochem Biophys 1996, 330:28I-284.

92. Yurchenco PD, O'Rear J): Basal lamina assembly. Curr Opin Cell Biol 1994, 6:674-68I.

93. Timpl R, Brown JC: Supramolecular assembly of basement membranes. Bioassay 1996, 18:123-132.

94. Fox JW, Mayer U, Nischt R, Aumailley M, Reinhardt D, Wiedemann H, Mann K, Timpl R, Krieg T, Engel J, Chu ML: Recombinant nidogen consists of three globular domains and mediates binding of laminin to collagen type IV. EMBO J I99I, I0:3137-3|46.

95. Rando RR: Chemical biology of protein isoprenylation/methylation. Biochim Biophys Acta 1996, 1 300:5-16.

96. Waters MG, Pfeffer SR: Membrane tethering in intracellular transport. Curr Opin Cell Biol 1996, I I:453-459.

97. Nielsen E, Severin F, Backer J, Hyman A, Zerial M: Rab5 regulates motility of early endosomes on microtubules. Nat Cell Biol 1995, I:376-382.

98. Meresse S, Gorvel JP, Chavrier P: The rab7 GTPase resides on a vesicular compartment connected to lysosomes. J Cell Sci 1995, 108:3349-3358.

99. Bucci C, Thomsen P, Nicoziani P, McCarthy J, van Deurs B: Rab 7, a key to lysosome biogenesis. Mol Biol Cell 2000, I I:467-480.

100. Jollivet $D$, Lallier $F H$, Barnay AS, Bienvenu $N$, Bonnivard $E$, Briand $P$, Cambon-Bonavita MA, Comtet T, Cosson R, Daguin C, Donval JP, Faure B, Gaillard M, Glippa V, Guillou L, Hourdez S, Le Bris N, Morand S, Pradillon F, Rees JF, Segonzac M, Shillito B, Thiebaut D, Viard F: The BIOSPEEDO Cruise: a new survey of hydrothermal vents along the South East Pacific Rise from $7^{\circ} 24^{\prime}$ 'S to 2133'S. InterRidge 2004, 13:20-26.

10I. Shillito B, Jollivet D, Sarradin PM, Rodier P, Lallier F, Desbruyères D, Gaill F: Temperature resistance of Hesiolyra bergi, a polychaetous annelid living on deep-sea vent smoker walls. Mar Ecol Prog Ser 200I, 2 I 6: I4I-I49.

102. Dixon DR, Pruski AM, Dixon LR: The effects of hydrostatic pressure change on DNA integrity in the hydrothermal-vent mussel Bathymodiolus azoricus : implications for future deepsea mutagenicity studies. Mutat Res 2004, 552:235-246.

Publish with Bio Med Central and every scientist can read your work free of charge

"BioMed Central will be the most significant development for disseminating the results of biomedical research in our lifetime. "

Sir Paul Nurse, Cancer Research UK

Your research papers will be:

- available free of charge to the entire biomedical community

- peer reviewed and published immediately upon acceptance

- cited in PubMed and archived on PubMed Central

- yours - you keep the copyright
BioMedcentral 